\title{
PENGEMBANGAN DAN PENGORGANISASIAN MASYARAKAT
}

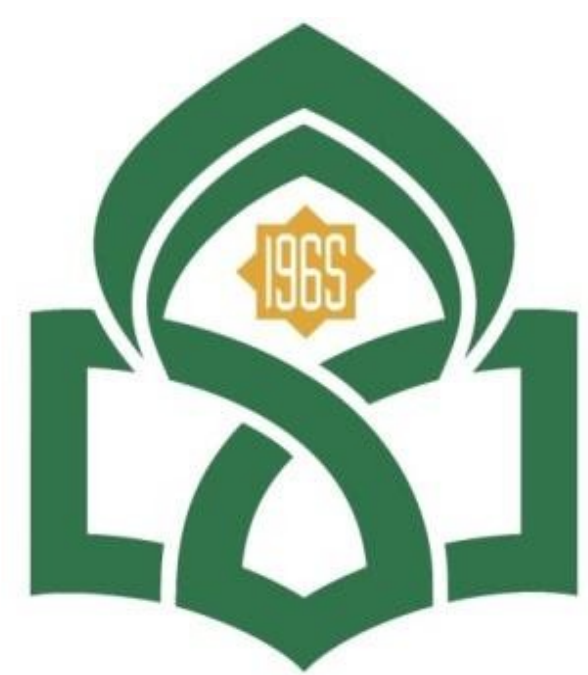

UNIVERSITAS ISLAM NEGERI

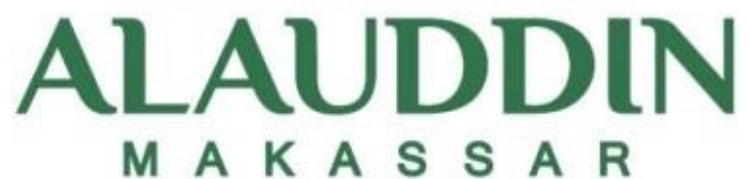

M A K A S S A R

Disusun oleh :

RISMAWANTY IDHAM

(70200119107)

PROGRAM STUDI KESEHATAN MASYARAKAT

FAKULTAS KEDOKTERAN DAN ILMU KESEHATAN

UNIVERSITAS ISLAM NEGERI ALAUDDIN MAKASSAR 


\section{PENGEMBANGAN KAPASITAS ORGANISASI DESA SEHAT DALAM MENURUNKAN KEJADIAN KEKURANGAN ENERGI KRONIK PADA WANITA USIA SUBUR}

\section{Pendahuluan}

Kekurangan Energi Kronik (KEK) adalah salah satu keadaan malnutrisi. Dimana keadaan ibu menderita kekurangan makanan yang berlangsung menahun (kronik) yang mengakibatkan timbulnya gangguan kesehatan pada ibu secara relatif atau absolut satu atau lebih zat gizi (Helena, 2013). ${ }^{1}$

Wanita usia subur (WUS) merupakan wanita yang terdapat pada rentang umur dimana pada usia tersebut organ reproduksi wanita mulai matang dan sudah berfungsi dengan baik dengan rentang usia 15-49 tahun termasuk wanita hamil, wanita tidak hamil, ibu nifas, calon pengantin, remaja putri, dan pekerja wanita. Kekurangan energi kronik yang sering menyerang pada wanita usia subur menggambarkan asupan energi dan protein yang tidak adekuat. Salah satu indikator untuk mendeteksi risiko KEK dan status gizi pada WUS dengan melakukakan pengukuran antropometri yaitu pengukuran Lingkar Lengan bagian Atas (LILA) pada lengan tangan yang tidak sering melakukan aktifitas gerakan yang berat. Nilai ambang batas yang digunakan di Indonesia adalah nilai rerata LiLA $<23,5 \mathrm{~cm}$ yang meggambarkan terdapat resiko kekurangan energi kronik pada kelompok umur wanita usia subur (Angraini, 2018). ${ }^{2}$

Prevalensi kurang energi kronik pada wanita usia subur, baik pada wanita hamil dan wanita tidak hamil berdasarkan hasil Riset Kesehatan Dasar (Riskesdas) Tahun 2013 menujukkan proporsi wanita usia subur dengan resiko KEK usia 15-49 tahun yang hamil sebanyak $24,2 \%$ dan yang tidak hamil sebanyak 20,8\% dan terjadi penurunan prevalensi KEK berdasarkan hasil Riskesdas Tahun 2018 menjadi 17,3\% 82 AL-SIHAH: THE PUBLIC HEALTH SCIENCE VOLUME 12, NO. 1, JANUARI-JUNI 2020 pada usia 15-49 tahun yang hamil dan 14,5\% wanita yang tidak hamil (KEK Nasional = 31,8\%). (Badan Penelitian dan Pengembangan Kesehatan, 2013, 2018). ${ }^{2}$

Kekurangan energi kronis pada WUS sedang menjadi fokus pemerintah dan tenaga kesehatan sekarang ini. Hal ini dikarenakan seorang WUS yang KEK memiliki risiko tinggi untuk melahirkan anak yang akan menderita KEK dikemudian hari. Selain itu, kekurangan gizi menimbulkan masalah kesehatan (morbiditas, mortalitas dan disabilitas), juga menurunkan kualitas Sumber Daya Manusia (SDM) suatu bangsa. Dalam skala yang lebih luas, kekurangan gizi dapat menjadi ancaman bagi ketahanan dan kelangsungan hidup suatu bangsa (Mboi, 2013). ${ }^{3}$

Faktor-faktor yang mempengaruhi KEK pada WUS terbagi menjadi dua, yaitu faktor internal dan eksternal. Faktor internal (individu/keluarga) yaitu genetik, obstetrik, seks. Sedangkan faktor eksternal adalah gizi, obat-obatan, lingkungan dan penyakit (Supariasa dkk, 2012). ${ }^{3}$ 
Pada kehamilan terjadi perubahan fisik dan mental yang bersifat alami. Para calon ibu harus sehat dan mempunyai gizi yang cukup sebelum hamil dan selama hamil. Status gizi ibu sebelum dan selama hamil dapat mempengaruhi pertumbuhan janin yang sedang dikandungnya. Seorang ibu hamil akan melahirkan bayi yang sehat bila tingkat kesehatan dan gizinya berada pada kondisi yang baik. Banyak ibu 2 hamil mengalami masalah gizi khususnya gizi kurang seperti KEK/ Kekurangan Energi Kronis dan anemia gizi (Agria, dkk. 2012:103). ${ }^{4}$

Salah satu masalah gizi yang dihadapi di Indonesia adalah masalah gizi dalam kehamilan. Kekurangan Energi Kronis merupakan salah satu masalah gizi yang terjadi pada ibu hamil. Kekurangan Energi Kronis merupakan keadaan kekurangan asupan energi dan protein pada wanita usia subur (WUS) yang berlangsung secara terus menerus dan mengakibatkan gangguan kesehatan (Pertika, dkk, 2014 Vol.2, No.3). ${ }^{4}$

Keadaan kesehatan dan status gizi ibu hamil sesungguhnya ditentukan jauh sebelumnya, yaitu pada masa remaja dan dewasa sebelum hamil atau selama menjadi Wanita Usia Subur (WUS). Intervensi untuk menurunkan permasalahan gizi di Indonesia khususnya pada anak-anak harus dimulai secara tepat sebelum masa kelahiran, dengan pelayanan prenatal dan pengaturan gizi ibu, yang 3 berlangsung hingga usia anak dua tahun. Namun, lebih dari sepertiga Wanita Usia Subur (WUS) di Indonesia tidak memenuhi persyaratan nasional untuk asupan makanan yang mengandung cukup energi dan protein (Indriani et al, 2013; UNICEF, 2012). ${ }^{4}$

Salah satu program yang dicanangkan pemerintah dalam dunia kesehatan dibidang gizi adalah "Gizi 1000 hari”. Program ini bertujuan untuk penerapan menyadarkan masyarakat akan pentingnya penerapan gizi pada 1000 hari pertama kehidupan anak dalam mencapai pertumbuhan dan perkembangan yang optimal (Kemenkes, 2016). ${ }^{4}$

Asupan energi dan protein yang tidak mencukupi pada ibu hamil dapat menyebabkan Kekurangan Energi Kronis (KEK). Wanita hamil beresiko mengalami 4 KEK jika memiliki LILA $<23,5 \mathrm{~cm}$. Ibu hamil dengan KEK beresiko melahirkan bayi berat lahir rendah (BBLR). BBLR akan membawa risiko kematian, gangguan pertumbuhan dan perkembangan anak. KEK juga dapat menjadi penyebab tidak langsung kematian ibu (Infodatin, 2016). ${ }^{4}$

\section{Pengembangan Organisasi Desa Sehat Dalam Menurunkan Kekurangan Energi Kronik}

Keterlibatan masyarakat di Desa khususnya remaja perempuan sebagai komunitas tempat tinggal wanita usia subur dan ibu hamil tentunya sangat diperlukan dalam upaya pencegahan dan penanganan kekurangan energi kronik pada wanita usia subur dan wanita ibu hamil, salah satu upaya untuk meningkatkan kualitas hidup wanita usia subur dan ibu hamil adalah terbentukanya satu dukungan dari masyarakat. Komunitas harus melakukan penyuluhan untuk pendekatan intervensi dalam merubah perilaku konsumsi pangan, seperti intervensi edukasi. Intervensi edukasi meliputi pelatihan pemanfaatan hasil untuk kebutuhan pangan keluarga. Selain itu, juga meliputi penyuluhan di Desa berupa pembelajaran tentang penyuluhan Pola Hidup Bersih dan Sehat (PHBS), dan penyuluhan gizi Bergizi Beragam, dan Berimbang (3B) (Almira, 2019). 
Oleh karena itu, perlu dilakukan suatu kegiatan Desa Sehat seperti penyuluhan atau sosialisasi kepada masyarakat terutama perempuan dalam mencegah Kurangnya Energi Kronik pada wanita usia subur dan wanita ibu hamil, seperti melalukan 4 pilar gizi seimbang tersebut.

Terdapat 4 (empat) pilar gizi seimbang yaitu,(Kemenkes RI, 2014):

1. Konsumsi aneka ragam makanan Makanan yang dikonsumsi harus mengandung semua jenis zat gizi yang dibutuhkan tubuh, porsi yang seimbang, dalam jumlah yang cukup, tidak berlebihan dan dilakukan secara teratur. Selain itu, minum air putih yang cukup karena penting untuk metabolisme tubuh dan pencegahan dehidrasi.

2. Membiasakan perilaku hidup bersih.

Prinsip kesehatan yang menjadi dasar pelaksanaan program Perilaku Hidup Bersih dan Sehat (PHBS) adalah mencegah lebih baik daripada mengobati. PHBS sendiri adalah semua perilaku secara sadar yang dilakukan oleh seseorang agar terhindar dari penyakit serta ikut serta dalam kegiatan di masyarakat yang berhubungan dengan masalah kesehatan.

3. Melakukan aktivitas fisik

Aktivitas fisik dilakukan untuk menyeimbangkan antara zat gizi yang masuk dan keluar dari dalam tubuh.

4. Memantau berat badan secara teratur untuk mempertahankan berat badan normal Indikator yang digunakan untuk mengukur keseimbangan zat gizi orang dewasa dikenal dengan sebutan Indeks Massa Tubuh (IMT). Pengukuran IMT perlu dilakukan secara teratur agar terlihat apakah terjadi penyimpangan atau tidak.

\section{Kandungan Zat Gizi Pada Biskuit Ubi Jalar Ungu}

Ubi jalar (Ipomoea batatas) merupakan komoditas sumber karbohidrat utama, setelah padi, jagung, dan ubi kayu, serta mempunyai peranan penting dalam penyediaan bahan pangan, bahan baku industri maupun pakan ternak. Sebagai sumber karbohidrat, ubi jalar memiliki peluang sebagai substitusi bahan pangan utama, sehingga bila diterapkan mempunyai peran penting dalam upaya penganekaragaman pangan dan dapat diproses menjadi aneka ragam produk yang mampu mendorong pengembangan agro-industri dalam diversifikasi pangan (Zuaraida dan Supriati, 2011). ${ }^{5}$

Kandungan gizi ubi jalar ungu varietas antin-3 yaitu sebanyak 150,7 mg antosianin, 1,1\% serat, $18,2 \%$, pati, $0,4 \%$ gula reduksi, $0,6 \%$ protein, $0,70 \mathrm{mg}$ zat besi dan $20,1 \mathrm{mg}$ vitamin $\mathrm{C}$ (Balitbangtan, 2016). ${ }^{5}$

Biskuit adalah produk yang diperoleh dengan memanggang adonan yang berasal dari tepung terigu dengan penambahan makanan lain dan dengan atau penambahan bahan tambahan pangan yang diijinkan. Biskuit diklasifikasikan dalam empat jenis yaitu biskuit keras, crackers, cookies dan wafer (Badan Standardisasi Nasional, 2011). ${ }^{5}$ 


\section{Kandungan Zat Gizi Roti Rumput Laut Lawi-Lawi (Ceulerpa racemosa)}

Produksi rumput laut nasional pada jenis lawi-lawi (ceulerpa sp) dalam kurun 2011-2015 menunjukkan kenaikan dengan rata-rata pertumbuhan 22,2 \%. Pada 2015, volume produksi rumput laut nasional sekitar 11,2 juta ton dengan nilai $\mathrm{Rp} 13,2$ triliun atau naik 9,8 \% dari volume produksi tahun sebelumnya sebanyak 10,2 juta ton (Kementrian Kelautan dan Perikanan, 2016). ${ }^{6}$

Rumput laut lawi-lawi memiliki kandungan gizi yang cukup tinggi sebagai sumber protein nabati maupun mineral. Jenis rumput laut ini, mengandung protein $17-27 \%$, lemak 0,08 - 1,9\%, karbohidrat $39-50 \%$, serat 1,3-12,4\%, dan kadar abu 8,15-16,9\% serta kadar air yang tinggi $80-90 \%$ (Verlaque et al, 2003 dalam Burhanuddin, 2014: 8). ${ }^{6}$

Roti merupakan produk olahan makanan yang terbuat dari tepung terigu yang difermentasi dengan ragi dan ditambahkan bahan pengembang lainnya serta memiliki aroma atau citarasa yang disukai konsumen kemudian dilakukan pemanggangan. ${ }^{6}$

Untuk menambah kandungan gizi produk olahan berbahan dasar rumput laut lawi-lawi, dibutuhkan penambahan pangan lokal lain yang dapat dioptimalkan keberadaannya dan merupakan sumber protein nabati serta kaya akan Fe dan zat gizi lainnya. Sebenarnya kualitas protein dari golongan nabati masih tergolong rendah dibandingkan protein hewani, namun kombinasi sumber nabati yang bervariasi mampu memberikan efek komplementari asam amino essensial (Winarno, 2002 dalam Estiningtyas, 2014: 9). ${ }^{6}$

\section{Hubungan Asupan Makan Dengan Kejadian Kurang Energi Kronis (KEK)}

Status gizi ibu merupakan hal penting sebelum konsepsi, (prakonsepsi adalah tiga bulan sebelum konsepsi). Janin paling rentan terhadap defisiensi gizi pada trimester pertama kehamilan, sering kali sebelum wanita menyadari kehamilannya, sehingga akan lebih baik pencegahannya dilaksanakan pada saat sebelum hamil (Garrow, 2014). ${ }^{7}$

Wanita usia 20-35 merupakan usia sasaran yang paling tepat dalam pencegahan masalah gizi terutama KEK. Rentang usia tersebut merupakan saat yang tepat bagi wanita untuk mempersiapkan diri secara fisik dan mental menjadi seorang ibu yang sehat sehingga diharapkan mendapatkan bayi yang sehat (Cetin, 2009). ${ }^{7}$

\section{Faktor Risiko Terjadinya Kurang Energi Kronis (KEK)}

Ada tiga faktor utama yang sangat memengaruhi kualitas sumber daya manusia (SDM), yaitu kesehatan, pendidikan, dan pendapatan. Status gizi pada negara berkembang terutama dipengaruhi oleh penyakit infeksi dan konsumsi makanan yang kurang. Sedangkan tingkat sosial ekonomi meliputi pendidikan dan pendapatan merupakan penyebab tidak langsung dari masalah gizi (Najoan, 2011). 


\section{Asupan Makan/Gizi}

Asupan makanan adalah sejumlah makanan yang dikonsumsi seseorang dengan tujuan untuk mendapatkan sejumlah zat gizi yang dibutuhkan oleh tubuh. Tiap zat gizi yang masuk akan memberikan fungsi yang penting bagi tubuh, misalnya sebagai sumber tenaga yang dapat digunakan untuk menjalankan aktivitas (Almatsier, 2009).

2. Penyakit Infeksi

Infeksi dengan keadaan gizi kurang merupakan hubungan timbal balik. Penyakit infeksi dapat memperburuk keadaan gizi dan keadaan gizi yang buruk dapat mempermudah infeksi. Malnutrisi menimbulkan bermacam-macam ancaman terhadap perempuan (Shafique, 2010).

3. Pengetahuan Gizi

Pengetahuan adalah hasil dari mengetahui dan terjadi setelah orang melakukan penginderaan terhadap suatu objek tertentu. Pengetahuan merupakan fungsi dari sikap manusia yang mempunyai dorongan dasar ingin tahu, untuk mencari penalaran dan untuk mengorganisasikan pengalamannya (Adhiyati, 2013).

4. Umur

Pada Wanita Usia Subur (WUS) kelompok umur 15-49 tahun prevalensinya naik 15,7 persen. Penyebab Kekurangan Energi Kronik (KEK) pada Wanita Usia Subur (WUS) karena keinginan atau obsesi untuk kurus yang melada para wanita 8 demi mendapatkan bentuk tubuh ideal dan status pekerjaaannya

5. Pendidikan

Pendidikan seseorang memengaruhi keadaan gizi karena diharapkan dengan tingkat pendidikan yang lebih tinggi membuat pengetahuan atau informasi gizi yang dimiliki menjadi lebih baik. Masalah gizi sering timbul karena ketidaktahuan atau kurang informasi tentang gizi yang memadai (Muliawati, 2012).

6. Pekerjaan

Pekerjaan seseorang dapat seseorang dapat secara langsung menggambarkan pendapatan, status sosial, pendidikan dan masalah kesehatan. Pekerjaan dapat mengukur status sosial ekonomi serta masalah kesehatan dan kondisi tempat seseorang bekerja (Najoan, 2011).

7. Pengeluaran

Pengeluaran merupakan proksi pendapatan yaitu untuk memperkirakan pendapatan seseorang. Kondisi sosial ekonomi keluarga memengaruhi kualitas dan kuantitas makanan yang dikonsumsi. Hal ini terkait dengan pengeluaran yang dikonsumsi sehari-hari. Pengeluaran dalam rumah tangga dibagi menjadi dua yaitu pengeluaran untuk bahan pangan dan non pangan (Najoan, 2011). ${ }^{7}$ 


\section{DAFTAR PUSTAKA}

1. Paramata Y, Sandalayuk M. Kurang Energi Kronis Pada Wanita Usia Subur Di Wilayah Kecamatan Limboto Kabupaten Gorontalo. Gorontalo J Public Heal. 2019;2(1):120.

2. Alam S, Ansyar DI, Satrianegara MF. Eating Pattern And Educational History In Women Of Childbearing Age. Al-Sihah Public Heal Sci J. 2020;12(1):81.

3. NURMILA. MANAJEMEN ASUHAN KEBIDANAN ANTENATAL CARE PADA NY "R" DENGAN KEKURANGAN ENERGI KRONIS DI PUSKESMAS SOMBA OPU GOWA TAHUN 2017. Univ Islam NEGERI ALAUDDIN. 2017;(1):1-133.

4. FATHARANNI M. HUBUNGAN PENGETAHUAN, SIKAP DAN PERILAKU MENGENAI GIZI SEIMBANG DENGAN STATUS GIZIPADA WANITA USIA SUBUR DI KECAMATAN TERBANGGI BESAR KABUPATEN LAMPUNG TENGAH. Kedokt Univ Lampung. 2017;4:9-15.

5. Syarfaini, Satrianegara MF, Alam S. Analisis Kandungan Zat Gizi Biskuit Ubi Jalar Ungu ( Ipomoea Batatas L . Poiret ) Sebagai Alternatif Perbaikan Gizi Di Masyarakat. Public Heal Sci J. 2017;9:138-52.

6. Syarfaini, Damayati DS, Susilawaty A, Alam S, Humaerah AM. Analisis Kandungan Zat Gizi Roti Rumput Laut Lawi-Lawi (Ceulerpa Racemosa) Substitusi Tempe Sebagai Alternatif Perbaikan Gizi Masyarakat. Al-Sihah Public Heal Sci J. 2019;11(1):95.

7. Putri M. HUBUNGAN ASUPAN MAKAN DENGAN KEJADIAN KURANG ENERGI KRONIS ( KEK ) PADA WANITA USIA SUBUR ( WUS ) DI KECAMATAN TERBANGGI BESAR KABUPATEN LAMPUNG TENGAH ( Skripsi ) Oleh MERISKA CESIA PUTRI. Univ Lampung. 2017;1-74.

8. Roehan AA. Kejadian Kekurangan Energi Kronik (KEK) Dan Pola Makan Pada Wanita Usia Subur (WUS) Di Wilayah Kerja Puskesmas Kelayan Timur. Univ Banjarmasin. 2015;D(2017):1-15.

9. Dian IA. Hubungan Faktor Keluarga Dengan Kejadian Kurang Energi Kronis Pada Wanita Usia Subur Di Kecamatan Terbanggi Besar. JK Unila [Internet]. 2018;2(2):14650. Available From:

Https://Juke.Kedokteran.Unila.Ac.Id/Index.Php/JK/Article/Download/1952/1919

10. Umisah IN, Puspitasari DI. Perbedaan Pengetahuan Gizi Prakonsepsi Dan Tingkat Konsumsi Energi Protein Pada Wanita Usia Subur (WUS) Usia 15-19 Tahun Kurang Energi Kronis (KEK) Dan Tidak KEK Di SMA Negeri 1 Pasawahan. J Kesehat. 2017;10(2):23. 